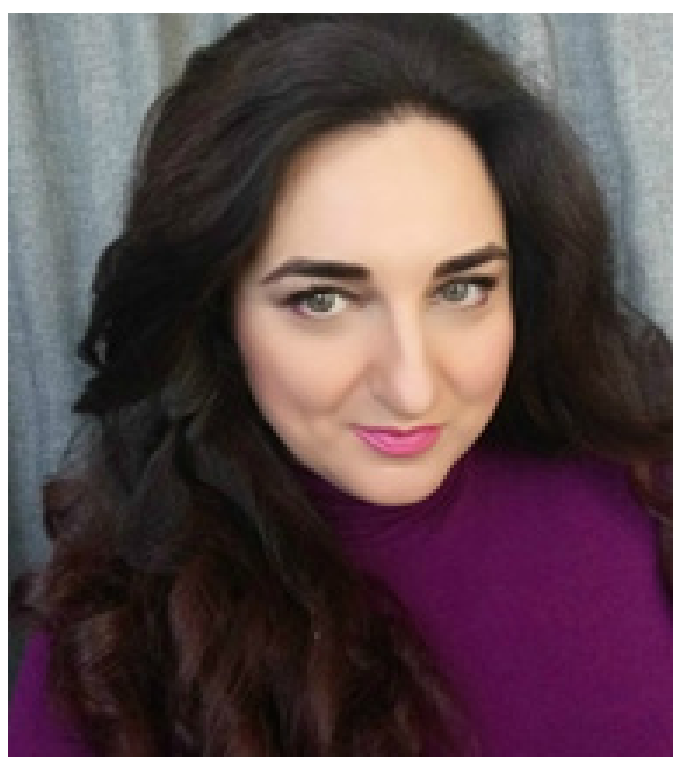

GENERATIONAL NOVELS AS A KIND OF A FAMILY NOVEL:

THE KEY ASPECTS OF THE GENRE FORMATION

doi: 10.34142/astraea.2020.1.2.05

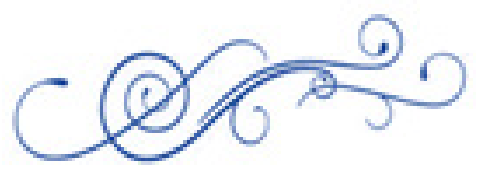

RUMIANTSEVALAKHTINA 0.0 .

postgraduate Department of Ukrainian Literature and Journalism named after Professor Leonid Ushkalov Kharkiv National Pedagogical University named after G.S. Skovoroda, methodist of the Center for Methodical and Analytical Work of the Municipal Higher Educational Institution "Kharkiv Academy of Continuing Education", Ukraine.

E-mail: roksik2911@gmail.com, https://orcid.org/0000-0001-7588-3395

\begin{abstract}
The article raises the problem of genre formation of the family novel in the theoretical aspect in the historical and literary process of the XIX century: the process of its development in Ukrainian and world literature is considered.

The purpose of this article is to try to define the features of the family novel as a genre that stood out in the world and Ukrainian literature of the Romantic era and realism.

A review of existing literary works on this issue, namely the works of I. Razumova, Z. Kirnose, Y-L. Ru, the use of the terms "family romance", "novel of generations", "family idyll", "family chronicle", "family narrative", "family decline" is substantiated. The common genre-style features and problems of family novels in different national literary contexts are revealed on the examples of T. Mann's "Buddenbrooks" and A. Svydnytsky's "Lyuboracki" and it is determined that the conflict of generations, the

(C) Rumiantseva-Lakhtina Oksana,




\section{Rumiantseva-Lakhtina Oksana}

decline of the family, the denial of traditions are common features of both works.

In the presented literary research A. Svydnytsky's family novel "Lyuborackyi" is considered in the context of expanding the boundaries of genres of domestic, social, historical novels, which emerged as a separate genre on national basis. The thematicproblem and space-time specifics of the novel are conditioned and the key aspects of genre formation of the novel of generations as a kind of family novel in the Ukrainian literature are determined.

Key words: genre, family idyll, family novel, generational novel.

\section{АНОТАЦІЯ}

\section{Генерація роману як вид сімейного роману: ключові аспекти формування жанру}

У статті порушено проблему формування жанру сімейного роману в теоретичному аспекті в умовах історико-літературного процессу XIX століття: розглянуто процес його розвитку в українській і світовій літературі, бо в сучасному літературознавстві немає чіткого визначення як терміна, так i типології сімейного роману.

Метою цієї статті $є$ спроба визначити особливості сімейного роману як жанру, що виокремився у світовій та українській літературі доби романтизму й реалізму та намагання розглянути концепцію становлення жанру сімейного роману в українській літературі, спираючись на погляди М. Бахтіна, який основними рисами сімейно гороману визначав як «сімейну ідилію», так i «зруйнування ідилій» на зламі епох у «романі поколінь».

Здійснено огляд наявних літературознавчих праць 3 означеної проблематики, а сааме робіт I. Разумової, 3. Кірнозе, Ї-Л. Ру, обгрунтовано застосування термінів “сімейний роман”, “роман поколінь”, “сімейна ідилія”, “сімейна хроніка”, “сімейний наратив”, “занепад роду”. Виявилено спільність жанрово-стильових особливостей, мотивів і проблематики сімейних романів у різнихнаціональнихлітературнихконтекстахнаприкладахтворів “Будденброки” Т. Манна та “Люборацькі” А. Свидницького й визначено, що конфлікт поколінь, занепад роду, заперечення традицій - спільні риси обох романів.

У представленій літературній розвідці сімейний роман А. Свидницького “Люборацькі” розглянуто у контексті розширення меж жанрів побутового, 
A

соціального, історичного романів, що виник як окремий жанр на національному грунті. Обумовлено тематико-проблемну й часопросторову специфіку роману й визначено ключові аспекти жанроутворення роману поколінь як різновиду сімейного роману, що став канонічним зразком розвитку цього жанру в українській літературі.

Ключові слова: жанр, сімейна ідилія, сімейний роман, роман поколінь.

\section{INTRODUCTION}

It should be mentioned that the focus of human literature has been concentrated on creating family chronicles, the defining feature of which is the storytelling of the family genealogy. The family narrative is one of the oldest types of narratives which has been intristic to the human culture and kept to nowadays.

In classical Ukrainian literature, the genre of family novel begins to develop in the nineteenth century. Among the works that can be defined as family, is the novel "Lyuboracki" by A. Svydnytsky, which is often referred to as a family chronicle. G. Kvitka-Osnovyanenko's novel "Mr. Khalyavsky" (1839) is one of the genre varieties of the family chronicle. The study of family novels in Ukrainian literature is carried out in most cases on the material of the XX-early XXI century. (I. Franko "Petriy and Dovbuschuk", U. Samchuk "Volyn" and "Maria"). The heyday of the family novel genre in Ukrainian literature reaches its apogee in the XXI century (V. Shevchuk "Shadows of the Disappeared", V. Lys "Jacob's Century" and "Solo for Solomiya", M. Mathios "Sweet Darussa", O. Zabuzhko "Museum of Abandoned Secrets " and other).

A Russian researcher of the family narrative in folklore sources I.O. Rasumova considers a family narrative as a complex of texts which exists in "a family communicative area" and shows the family to the world. These texts include the level of family relationships and serve to transfer the gained experience and reflect peculiarities of relations within the family (Rasumova, 2011). She indicates that family memory has such features as selectivity, individuality, a special attitude to "memorizing" and "forgetting", giving preference to the meaning of events to their actual side. I.O. Rasumova draws attention to the fact that "the inner time" of a family is being considered on two levels - "the genealogical time"("the time range of a particular group that is represented in terms of generations - from the ancestors in the past to the offspring in future") and family time that includes linear and cyclic 
models : a change of generations and a reproduction of a family group". An overall (calendar) chronology is limited in a family historical narrative. The basis is the time of the event, dating is secondary (Rasumova, 2011). These features of the family narrative are intristic to the genus history in oral folk art and a literary text.

\section{LITERATURE REVIEW}

What does the term "family novel" mean? In modern literature there is no clear definition of the term and the typology of the family novel. Among American and Russian literary sources where there are similar studies, the most common terms are "family chronicle", "family saga", "family narrative" but there are no common criteria for the specific classification of this literary genre. It should be noted that there is no single approach to define the term "family novel" and there are also no common criteria for the intraspecific classification of this literary genre. Despite the intensity of this literary polemic the term "family novel" could not find a proper place in literature textbooks and reference books and dictionaries of literary terms that had not included separate articles dedicated to the genreuntil the early 200os.Wed idnotfindtheminsuchwidespreadandpopularin the Soviet and post-Soviet (including Ukrainian) intellectual and scientific dictionariesas "The Dictionary of Literary Terms" by V.M Lesin and O.S Pulinets (K., 1971), in the "The Short Dictionary of Literary Terms" by S.V. Turaev (M., 1978) and other publications.

For a long time the attention of researchers was involved in the structural and compositional features of family chronicles in which they saw another variant of the genre. In particular, this approach was outlined by Z.I. Kirnose. Noting the structural heterogeneity of the family novel, Z.I. Kirnose justifies the need to separate the family novel and the family chronicle. In her opinion, a family domestic novel requires a detailed description of life, characteristics of a social environment. Furthermore, the difference of behavior, evaluation of events, self-perception of heroes forces the author to deep psychological analysis. In the family-novel "a family conflict arises as a conflict of nature, locked in a circle of chosen circumstances" as Z.I. Kirnose notes (Kirnose, 1977). All features of a family novel are organically inherited by family chronicles. However, family chronicles are characterized by ways of expanding the narrative framework, engaging historical events that point to the prospects of nationwide development that is built on the principle of historical approach. 
n our opinion, M.M Bakhtin presents the whole concept of forming the genre of a family novel in a work called "The forms of time and chronotope in the novel" where the genesis of the genre and its main structural features are traced. The literary critic separates the features of a classic family novel and signs of a generational novel. The literary critic does not define neither a family novel nor a family chronicle but he determines the ways of its differentiation. He does not operate the term "family romance" but clearly defines the issues and motives of the genre of the generational novel. According to Bakhtin, "Generational novel" arises at the turn of the epochs, caused by a cataclysm in the society and the "destruction of idylls"(Bakhtin, 1975:384).

The research of the genre requires the identification of an appropriate problemthematic paradigm because the genre of a family novel implies a thematic affinity of works of different genres. The family novel brings together many stories of the family life in different generations. A characteristic feature of such a novel is the presence of an internal family conflict and aggravation of family relationships. The crucialvalue for the whole architectonics of the genreliesina nature of a person's connection with other family members and relationships between them have a number of features of a private nature and are built on the principle of movement from organic unity to rupture (Bakhtin, 1975:365). An idyllic moment is crucial in a novel of generations according to Bakhtin. In a generational novel a hostile power breaks into the world of the family and destroys the idyllic patriarchal system unlike a family novel. The special emphasis of the family novel is put on interaction between representatives of different generations who are typical in their outlook, in a search of values and in the choices of ways of self-determination. Generations differ in the way they think and the spiritual experience. The family can become a discouraging and even a hostile force for the person. The backwardness of artificially supported foundations often deprives the family of the necessary dynamics for self-reproduction which causes its degeneration. In the image of the family you can see the expression of eschatological mythology. On the other hand, the family will always remain the moral and ethical support of becoming a human personality, a test of self-sufficiency as the natural form of human relationships. Therefore, family can be seen as a typical phenomenon of the social order, as an example of the development of a moral defect (on the principle of the "curse of the race"), which was born inside a clan but caused by outside influence, which becomes a symbol of time or it can serve as a unique model of interpersonal relationships. (Allamuratova et al., 2014) (Allamuratova et al., 2014: 1187). 


\section{AIM OF THE ARTICLE}

A serious break in the image of family relationships occured in the literature of XIX-XX century when the psychology of a personality and the specificity of confrontation between a human and society began to be analyzed. The theme of the tragic decline of generations reflected the degradation and defects of society in the literature and provided an opportunity to expand the genre differentiation of the novel in the areas of romanticism and realism. The main purpose of the article is to investigate which traits of the family narrative are appropriate to the novels "Liuboratski" by A.Svidnytskyi and "Buddenbrooks" by Thomas Mann and to prove the hypothesis of M.M Bakhtin that both family novels can be considered as "generational novels" by genre.

\section{METHODOLOGY}

Methods of analysis and classification.

The method of classifying genres of family novels was first applied by M.M. Bakhtin in his work "Forms of time and chronotope in the novel". The scientist talks about the family romance in the section on the idyllic genre. The researcher identifies a separate type of idyll - a family idyll. At the same time, he notes that "family idyll in its pure form is almost never found, but in combination with agricultural labor is very important" (Bakhtin, 1975:375). Bakhtin for the first time points to two main types of family romance in world literature.

It gives rise to new genre varieties of the family novel, among which he singles out the "family novel" and the "novel of generations" (Bakhtin's terms). The literary critic does not single out the family novel as a separate genre, but determines the ways of its differentiation. He does not use the term "family novel", but outlines the issues and motives of the genre "novel of generations". This classification seems to us to be fundamentally important for the study of the family novel as a genre. The method of classification of a family novel, proposed by Bakhtin, is used in the article.

\section{RESULTS}

Let us try to consider how T. Mann and A. Svidnytskyi have portrayed the decline 
A

of families, how the two types of the worldview have been contrasted. Patriarchal values are represented by the older generation, trying to keep old traditions but the younger generation seeks to adapt to other social conditions and selects the values of the new era.

A modern researcher of a family novel Ru Yi-Ling thinks that one of the first family novels in the world literary tradition is "Budenbrooks" by T. Mann. She says, "it is the first prototype of a family novel in the West that marks the rapid development of this sub-genre because it shows a more distinctive form that separates it from other types of a novel" (Ru Yi-Ling, 1992:4). The researcher considers that a family novel "developed new aspects by inheriting the literary traditions of the previous periods" in the twentieth century (Ru Yi-Ling, 1992:165). While using the established form, a family novel adds new energy to this literary genre by introducing new ideas, taking different approaches to old problems, using innovative techniques (Ru YiLing, 1992:165).

In the semantic structure of the term family novel we distinguish the meaning, which signals the connection of the novel as a literary genre with the concept of family and social group consisting of married people, their children and relatives, and acts on the basis of general economic, domestic, moral-psychological lifestyle.

The semantic load of the first word in the title of the genre "family" specifies the features of this novel on a formal and semantic level and distinguishes this type of novel from others (adventure, psychological, detective novels, etc.). This aspect of genre formation determines the study of peculiar issues, plot aspects of the work, as well as categories of time and space. In the context of the issue, it should be noted that the family novel explores the traditions of the family, its microclimate, the problems of parents and children, as well as the study of conflicts and social ties of the family.

The spiritual and moral vector of family novels is evident in the means of genre formation and in the features of their poetics. The historical and generic basis of the story forms the typical heroes. The key figure is the ancestor of the family - the "originator of the genus." The story about him, his portrayal or some of his features are the source of the story that naturally grows in the system of heroes: "greatgrandparents", "grandparents", "grandmothers", "sisters", "brothers", "aunts", "uncles", "daughters", "sons", "nephews", etc. ... Usually, referring to one of the representatives of the genus, the narrator seeks to offer the reader all the family "branches" of this character. 
Thomas Mann defines the theme of the novel "Buddenbrooks" as "the fall of the burgher house." The program of the storyline is defined in the subtitle of the novel "the decline of one family". The father of the family Johann Buddenbrook heads the house and is the owner of the firm, embodying the authoritarian structure. The burger house has a production because the concepts of family and business were synonymous at that time. Everything in the house is created on their own. This does not contribute to the development of trade relations but makes it possible to use cheap labor. "The old benefactor was not a man who is unable to do something. He saw the world, on the thirteenth year went to the south of Germany to buy grain for the Prussian army. Also he visited Paris and Amsterdam and, as an educated man, did not consider that everything at the gate of his country is worthy of rebuke. Yet, where business relations ended, in public life, he was a greater supporter of strict delimitation... "(Mann, 1973). Therefore, the family authority of the father has been economically conditioned. He rules the house because he makes money and owns capital. It seems that the upbringing function of children is normatively owned by the father but mother takes care of them throughout the history of the family, because the head of the family is completely absorbed by work at the firm. The process of change in burgher families accelerates. The work in the company and family life are separated from each other so there is a redistribution of ethics that affects generations.

The novel "Liuboratski" by A.Svidnytskyi shows the history of the decline of the family on the Ukrainian national soil. Despite years of oblivion, the work impresses readers and researchers with its "condensation" that is not inferior to the novels of the twentieth centuryas V. Shevchuknotes.

The novel "Liuboratski" by A.Svidnytskyi went to his reader for almost 40 years. The first part of the work was written in 1861 and was published in January 1862 in "Fundamentals". The second part was almost completed in the spring of 1862, but the writer did not send it to the journal because it did not receive a response from the editorial about the first part of the work. In 1886 in the publishing house called "Zoria" the text of the novel was printed with the assistance of I. Franko. And only in 1901 in Kiev the full edition of the novel "Liuboratski" was published. The author determines that the genre of the novel is a family chronicle. The theme of the novel is the story about the family of the priest Liuboratskyi in three generations: Gervasiy and his wife, their children Masia, Antos, Oryssia and Teklia, their grandson Phonia who is Oryssia's son. 
Unlike the Buddenbrooks family where the authoritative head is old Mr. Buddenbrook, in the Liuboratski family the mother is the custodian of the genus and the bearer of the family memory. Perhaps this is due to the cultural traditions of Ukrainians and the role of the mother, who is the guardian of the family. Her life is little different from the life of a simple peasant. She works hard every day and teaches her children. Of all the heroes of the novel Mrs. Luboratska stands close to the roots of her people and keeps national values. She teaches her oldest daughter Masia and says, "You are from a noble family, an ancient family"(Svidnytsky, 2006:113) because her great-grandfather had consecrated the knives of the haidamaks, her grandfather participated in Koliyivshchyna and fought for faith and freedom. The old priest's wife has a dual nature. This can be traced in her attitude to ordinary people. "She (MrsLiuboratska) does not prohibit to socialize with rural girls but strongly does not allow to fraternize with them"as V. Sivachenkonotes. (Sivachenko, 1962). She has a negative attitude to education and constantly repeats her father's words: "theyarenotdisciples, they aremartyrs; they are not teachers, they are torturers “(Svidnytsky, 2006:70).

Father Gervasius who was the ancestor of the Liuboratski family is a typical representative of the clergy of Podil in the 1940s-1950sthat "was respectedby thecommunityandthe community respected him; andthey did not shun the lordsbecausetheyknewthey can take something from them"(Svidnytsky, 2006: 51). $\mathrm{He}$ is a good priest and polite in relationships with parishioners. There is respect between him and his wife, peace and harmony reign in the family. They use the word "heart" addressing to each other with warmth and love. Father Gervasius is a good host, a caring father and a loving husband. But the laziness of the priest has led him to not being concerned with their children's upbringing in the spirit of the traditions of his own people. "Father Gervasius feared nothing as much as God's punishment for the plight of children and he was lazy because he put everything off."(Svidnytskyi, 2006:59). Priest Liuboratskyi "initiates the departure of his children from ... harmony" of life according to the traditions and customs of the ancestors as V. Shevchuk notes. (Shevchuk, 2006: 25)

Both novels have an autobiographical background. 'Buddenbrooks" are written on the basis of the family "Bible" by Mann and the novel "Liuboratski" shows the life of the writer Anatoly Svidnitsky who took prototypes of the characters from his own family: theauthor'sfatherPatrykiySvidnitsky, a priest, who was a deacon for a long 


\section{Rumiantseva-Lakhtina Oksana}

time without education and become a priest only at the age of 36 . He learned to "read, sing and the church charter"(Sivachenko, 1962:177); the author's sister Maria (Masia's prototype) studied at Mrs Werner's Polish school in Ternivka (Gerasimenko, 1959). The writer himself received his education as AntosLiuboratsky at the Krutian Theological College and Kamianets Theological Seminary. The writer portrayed the reality that surrounded him and the social stratum of society which he came from.

The descendants of Buddenbrook and Liuboratski have a common motive. This is the motive of "lost children". Even in the first generation of Buddenbrooks there is a hint of a family destruction: The home of Johann's father is abandoned by his eldest son Gothold. Tony and Christian Buddenbrook also leave their parental fortress which was their refuge. Antonia lives a very humble, secluded life in the first and the second marriages. After two divorces the woman returns to the house on Mengstrasse which has become her great salvation. After her parents' house has been sold, Tony feels confused and unprotected, and she and her daughter have to rent an apartment. The fate of Christian Budddenbrook, who is not interested in burgher activity at all, is tragic. As a real "prodigal son" he constantly "wanders" from place to place returning to the roof of his parental home from time to time. His marriage with a "suspicious woman" becomes a parody of a true patriarchal burger family. Finally, frustrated and broken Christian finds himself in the four walls of a psychiatric hospital after selling his parental house.

The image of Thomas Buddenbrook is interesting. He does not disappear from the house and at the first glance seems successful: in the spirit of burgher traditions, Thomas, Christian's older brother, is trying to continue the family's business. But Thomas is trying to impose artificially the "nature" of a wealthy merchant and patrician. For a while, he even manages to do it. It seems that Thomas Buddenbroke has a brilliant career and endows Buddenbrook's burgher house with nobility because he is the first who becomes a senator and builds his own house. But he lacks the strength of spirit, fundamentality, and his weakness gradually destroys the personality. Thomas Buddenbrook's "tradition" eventually turns into empty, low-quality acting. And he destroys the amulet of the Buddenbrooks, the home on Mengstrasse, by selling it to the rivals. A weak, sickly boy who was a descendant of Thomas Gunn crosses out the family history saying:"It seems to me that after something there will be nothing"(Mann, 1973;177).

Antos is the prodigal son in the novel "Liuboratski". He grows up to be a smart 
boy who, at the age of eleven, was "ready to be a great person," but Father Gervasius sends his only son to learn science in the Orthodox seminary. The guy becomes completely modified there. First, young Antos seeks social justice:

"When I go to the priesthood, I will start to work at school, I will teach children, I will stand for the community before the lord, before the court, before the king ... Will they flout? So what? I will follow the Christ» (Svidnytsky, 2006:145). He tries to protest against scholasticism, in human abuse of the Bursacs (for every guilt the students were beaten with a caning until losing consciousness).

But what could one young man do against the entire system of anti-human laws? At first, someone humiliates Antony's dignity. He, one of the most perspective students, leaves the seminary «without a degree». Then he is blackmailed and to get a parish he has the only way out - to marry a spinster, and Galia, who sincerely loved Antos, marries the other guy. In the prime of his life, devastated and broken, Antos degrades: at first he drinks and then dies.

The father convinced by Rosolynskyi, sends his eldest daughter Masia to study in a Polish school where the girl was completely changed and from a working, responsive girl under the psychological pressure of surrounding people turns into a lazy girl. She begins to speak only Polish and was ashamed of her mother. "She was only with Poles and she went to churches and monasteries; she did not show a nose to her church... the last drop of blood ... drew from her mother" (Svidnytsky, 2006:119)Masia becomes a cruel and vicious polish girl. She returns home only to retrieve her last possessions from her mother and even picks up a pillow. To receive Polish nobility the girl marries a widower, MrKulinskyi, whose children leave Masia in poverty. She degraded morally and, as a consequence, committed a suicide.

In our opinion, the fate of Oryssia is the most tragic. Having arranged the marriage of the girl and the priest Timokha, the old priest's wife hopes to live happily with her grandchildren. But the son-in-law scoffs at the old woman, kicks her out of the house, and eventually deprives little Fonia of his mother: he killsOryssia whenshepleadsforparishioners. Old MrsLiuboratskadiesontheroad, andFeklafindsherselfin a monastery. ThefamilyoftheUkrainianclergy, whichoncecon secratedtheknivesofthe haidamaks, hasfinallydeclined. 


\section{DISCUSSION}

Attention should be paid to the chronology of the family narratives of "Buddenbrook" and "Liuboratski", to the temporal sequence of events. The novels gradually reveal family stories over several generations, their family relationships against the background of social events in a linear sequence that is considered a sign of family chronicles. Researcher E. Nikolsky defines the genres of novels as family chronicles: "It is necessary to pay attention to the chronology of the family narratives of "Buddenbrooks" and "Lyuboratski", to the temporal sequence of events. The novels gradually reveal family stories in several generations, their family relationships against the background of social events in a linear sequence, which is considered a sign of family chronicles". (Nikolsky, 2009).But, in our opinion, the principle of historicism in both novels is not clearly defined. Family relationships are depicted at the turn of the ages. Thomas Mann depicts the disintegration of the bourgeois family under the pressure of capitalism, and in A. Svydnytsky's novel "Liuboratski" it is not only the decline of serfdom and the emergence of capitalist relations, but also the inability of Ukrainians to realize their national identity and overcome inferiority complex.

\section{CONCLUSION}

Thus, having carried out a comparative analysis of T. Mann's novel "Buddenbrook" and A. Svidnytskyi's "Liuboratski", we can assume that both works are family novels, namely, generational novels (and T. Mann defines the genre of the novel as the decline of one family). External influence and personal qualities destroy traditional families in Germany and in Ukraine, and the decline of patriarchal families always occurs amidst social conflicts. But in our opinion, the problem of "Liuboratski" by A. Svidnytskyi is much deeper and more tragic. The Buddenbrook family loses only material possessions and the house, and only then breaks down, but the Liuboratski family forgets the roots of their own genus, i.e. declines spiritually, so all its descendants gradually degrade and they are killed. In our opinion, A. Svidnytskyi, hinting at the uncertainty of the Ukrainians, reveals the impossibility of overcoming the inferiority complex under the influence of the cultures of the two empires (Russia and Poland) and defines the genre of the novel as a family chronicle, determined by 
the linear principle of the plot construction (chronological sequence) and the principle of historicism. But this is just a hint of historical events, so if you look more closely and observe the behavior of each of the Liuboratski, one can understand that it is the low spirit that causes the spiritual degradation of the family and the moral decline of the personality of each member. The "family idyll" observed in the family at the beginning of the work is destroyed not only by external factors: it is facilitated by the microclimate of uncertainty and indifference of senior Luboratski, the desire of posterity to adapt. This leads to the hypothesis that the genre of "Liuboratski" by A. Svidnytskyi can be formulated not only as "the first realistic novel on a household background" (as I.Franko notes)(Franko, 1980:7), and as the first family novel, a generational novel that has become the catalyst for the development of the family novel genre in Ukrainian literature.

Funding: This study received no specific financial support.

Competing Interests: The author declares that there are no conflicts of interests regarding the publication of this paper.

\section{References}

Allamuratova, A. Zh., Allamuratova, G. Zh.(2014). K voprosu o zhanre semeynogo romana [To the question of the genre of a family novel]. Retrieved from https:// moluch.ru/archive/63/9724 (in Russian)

Bakhtin, M.M. (1975) Formy vremeni i khronotopa $v$ romane [Forms of time and chronotope in the novel]. Moscow: Khudozhestvennaia literature (in Russian)

Bernads'ka, N.I. (2004) Ukrayins'kyy roman: teoretychni problemy i zhanrova evolyutsiya [Ukrainian novel: theoretical problems and genre evolution]. Kyiv: VTs «Akademvidav» (inUkrainian).

Franko,I.YA.(1980)Anatol'PatrykiyovychSvydnyts'kyy(uvahyyoho“Lyuborats'kykh") [Anatol Patrykiiovych Svydnytsky (attentionofhis «Lyuboratsky»]. Kyiv: Vts «Naukova dumka» (in Ukrainian).

Halych, O., Nazarets', V., Vasyl'yev, YE. (2001). Teoriya literatury: Pidruchnyk. [Literature theory: textbook]. Kyiv: Vts «Lybid» (in Ukrainian).

Herasymenko, V. YA. (1959) Anatoliy Svydnyts'kyy. Literaturnyy portret [Anatoliy Svydnytsky. Literary portrait]. Kyiv: Vts «Derzhavne vydavnytstvo khudozhn'oyi literatury» (in Ukrainian).

Kirnoze, Z.I. (1977) Frantsuzskiy roman XX veka [French novel of the twentieth century]. Gor'kiy: Volgo-Vyatskoyeknizhnoyeizdatel'stvo.(in Russian).

Kratkiyslovar' literaturovedcheskikhterminov(1978) [Brief Dictionary of Literary Terms] Moscow: Prosveshcheniye (in Russian).

Mann Thomas. (1973) Buddenbroki [Buddenbrooks]. Retrieved from https://www. ukrlib.com.ua/world/printit.php?tid=3620 (in Ukrainian). 
Nikol'skiy, Ye.V. (2009) Zhanr romana semeynoy khroniki $v$ russkoy literature rubezha tysyacheletiy [The genre of the family chronicle novel in Russian literature at the turn of the millennium]. Retrieved from https://cyberleninka. $\mathrm{ru} /$ article/n/zhanr-romana-semeynoy-hroniki-v-russkoy-literature-rubezhatysyacheletiy/viewer (in Russian).

Porokhnyak, N. (2010) Roman - simeyna khronika z pohlyadu literaturoznavchoyi antropolohiyi [Roman is a family chronicle from the point of view of literary anthropology]. Retrieved from http://nbuv.gov.ua/UJRN/Pl_2010_79_21 (in Ukrainian).

Porokhnyak, N. (2011) Simeyna khronika «Lyuborats'ki» A. Svydnyts'koho yak roman pro zanepad rodu [Family chronicle "Lyuboracki” by A. Svydnytsky as a novel about the decline of the family] Retrieved from http://dspace.tnpu.edu. ua/bitstream/123456789/3355/1/Porokhniak_Nataliia.pdf (in Ukrainian).

Razumova, I.A. (2011) Kognitivnyye osnovy semeynogo narrative [Cognitive foundations of family narrative]. Retrieved from http://www. ruthenia.ru/ folklore/rasumova_4.htm /15.03.2011/ (in Russian).

Ru Yi-Ling. (1992) The family Novel. Toward a generic definition. New York: Peter Lang Publishing Inc., p. 215.

Shevchuk Valeriy. (2006) Klasyk "rozumnoho bytopysu"/Valeriy Shevchuk // Peredmova do vydannya: A. Svydnyts'kyy. Lyuborats'ki. Opovidannya. Narysy ta statti Shevchuk Valeriy. Classics of "smart biography" / Valery Shevchuk // Preface to the publication: A. Svydnytsky. Lyuboratsky. History. Essays and articles] Kyiv: A.S.K. (in Ukrainian)

Svydnyts'kyy, A. (2006) Lyuborats'ki. Opovidannya. Narysy ta statti. Story [Stories, essays and articles]. Kyiv: A.S.K. (in Ukrainian).

Syvachenko, M. YE. (1962) Anatoliy Svydnyts'kyy I zarodzhennya sotsial'noho romanu $v$ ukrayins'kiy literaturi. Monohrafiya [Anatoliy Svydnytsky and the origin of the social novel in Ukrainian literature. Monograph]. Kyiv: Vydavnytstvo Akademiyi nauk Ukrayins'koyi RSR(in Ukrainian).

Received: 19.06 .2020

Accepted: 20.08 .2020

\section{Cite this article as:}

Rumiantseva-Lakhtina, O.O. (2020). Generational novels as a kind of a family novel: the key aspects of the genre formation. Astraea, 1(2), 88-101. doi: 10.34142/ astraea.2020.1.2.05 